\title{
MPP2 Gene
}

National Cancer Institute

\section{Source}

National Cancer Institute. MPP2 Gene. NCI Thesaurus. Code C24610.

This gene is involved in cytoskeletal modeling, cell proliferation and intercellular communication. 